\title{
StandUpMigranten: The Role of Television Comedy for the Discourse on Migration in Germany
}

\author{
MARTIN R. HERBERS Zeppelin Universität Friedrichshafen, Germany
}

\begin{abstract}
Dominant positions shape political discourse. They are brought forth by politicians and journalists alike, and impact social reality. With regard to migration discourse, strong images of repulsion, such as 'Fortress Europe', perpetuate a highly conservative stance. Nevertheless, these images can be subverted through comedy. The paper reviews the German television comedy show StandUpMigranten, which revolves around topics of immigration to Germany. Comedy subverts stereotypical depictions of immigrants and discusses them against the backdrop of comedy theory and its role in public discourse.
\end{abstract}

\section{KEYWORDS}

Television comedy, political discourse, migration, orientalism

\section{Introduction}

Europe (and the European Union) can be described on many levels: geographically it is a continent, politically it is a union of 28 sovereign states that operate through supranational institutions, and economically it can be depicted as a single market. As these descriptions are rather unambiguous, describing Europe on a cultural level proves rather difficult. A variety of national and supranational groups as well as subgroups can be found, featuring different cultures and symbolic expressions, without a superimposed form of 'European culture'. The internal organisation of these groups lies on a national and regional level, which performs the idea of Europe through its cultural heterogeneity (Lichtenstein 2012). The idea of a unified Europe is especially shied from in time of so-called crisis. Here, national and cultural borders are not lowered in order to find a joint solution, but rather are raised in retreat. Examples, such as the monetary crisis, the Ukrainian crisis and the on-going migratory crisis evoke the repellent, yet powerful image of 'Fortress Europe'.

The idea of 'Fortress Europe' is a strong image, which has recently perpetuated in political discourse and journalism on a national and supranational level in Europe, evoking a powerful stance of anti-migratory rhetoric. Yet, there are different strategies of subversion. The paper at hand asks how comedy - as a specific type of rhetoric - can serve as a communicative strategy to subvert dominant discourses. Based on a review of the German comedy show StandUpMigranten, this paper argues that counter-rhetoric is possible, and even bears the option of emancipation from dominant messages, especially if used by migrants as the dominated group themselves. 


\section{The Rhetorical Construction and Abrasion of the Fortress Europe}

The notion of "Fortress Europe" was initially used in the Third Reich, where it served as a self-description for the Nazi-occupied parts of Europe, evoking medieval imagery of an impenetrable fortification; a stronghold used for defending an 'internal unity' (another popular expression of Nazi propaganda) against the outside world (Schmitz-Berning 2000). The original meaning of this expression has become obfuscated in recent political discourse, making it a household metaphor for journalists, used to describe political discourse on European foreign politics. The assumption of Europe being a unified political and cultural space, which has to be defended against third parties, is a readymade expression especially used by conservative forces in European politics and journalism (Zandonella 2009). Against the backdrop of recent discourses on migration to Europe, it is used to describe policies of foreclosure, control of migratory processes, anti-terrorism and border controls, both international and national. On an international level, for example, it is used to legitimise the actions of Frontex in the Mediterranean Sea in order to stop (illegal) migration to Europe (Gerson, 2015). On a national level, for example, by the German right-wing populist group PEGIDA (Patriotische Europäer gegen die Islamisierung des Abendlandes; in english: Patriotic Europeans against the Islamisation of the West (Occident); Geiges, Marg \& Walter 2015). This provokes a powerful rhetorical image with a strong message. It tells migrants, seeking refuge from dictatorship, persecution and poverty to stay out of Europe and its member countries, and - at the same time - tells European politicians to take actions to defer migrants, as otherwise, 'Fortress Europe' will fall.

Processes of counter-rhetoric on an international or national level are scarce and seldom find their way into media accounts on migration. Nevertheless, some voices are heard: German chancellor Angela Merkel's invocation "We can do it!" is a plea for opening national (and international) 'fortified borders' for those that seek refuge, bringing a strongly humanistic position into the current debate (Vick \& Schuster 2015). It is but the starting point of a 'new' political and journalistic discourse on migration in Germany, which in the latter is dominated by conservative viewpoints (Bade 2015), with the clear demand for migrants to fully integrate into German society. As a result and given the historical backdrop of German asylum politics, recent developments show a more liberal attitude towards migrants to Germany. For example, Die Tagesschau, Germany's major television news magazine has developed an online-version of its newscast in Arabic language and journalists developed a more sensitive, non-populist view in covering migrant life, giving background information and more personalised accounts on migrants. Despite being politically neutral in its stance it focuses on rather conservative reporting on migrants. The show presents strong mediated messages, as they are institutionally produced reports on migrants and services for migrants, but not by migrants. This seemingly overwhelming situation leads to a construction of social reality through powerful communication (Schulz 1989), which cannot easily be subverted, as most migrants do not have the resources to voice their points of view and their accounts on their situation in the media. In order to subvert these established processes, a different rhetorical strategy has to be employed by migrants in order to a obtain voice and gain visibility of their own accounts and thus emancipate themselves from the situation of being talked about. A different strategy needs to be employed, which takes the dominant discourse as a starting point, but re-frames it in favour of those that are generally excluded from it. This rhetorical strategy discussed in this paper is comedy, which subverts dominant rhetoric by giving excluded groups the opportunity to voice their opinion in political discourses and reusing its properties for their own position (Paletz 1990). 


\section{Comedy and the Subversion of Dominant Rhetoric}

Comedy's subversive potential can be described from two perspectives: on the one hand, it serves a societal function; on the other hand, it acts as a social-psychological mechanism, which underlies group formation. On a societal level, comedy can be regarded as a subversive form of symbolic construction of reality. German philosopher Siegfried J. Schmidt (2003) proposes that comedy is a societal force, necessary to shine a light on the often-opaque arbitrary symbolic construction of social reality. Following the ideas of 'communicative constructivism' (as discussed deeper in Herbers 2014), Schmidt is in line with Winfried Schulz's (1989) argument that mediatised communication cannot depict reality as such. Communication, especially in its mediatised form, relies on symbols that are arbitrarily coded references of elements of the 'real world', which are only understood in the context of a certain society and culture. In the course of signification, certain societal meaning is brought forth and 'attached' to a certain reference. As a result, the process of 'meaning-making' is connected to power, as certain societal forces or social groups define a reference's meaning and interpretation.

Mediatised communication must rely on these established meanings in order to be successful, thus perpetuating inscribed propositions, which the audience needs to decode (Hall 1979). Schmidt (2003) argues that comedy should be seen as a special form of communication, which playfully subverts the 'regular' communicative process and its perpetuated meanings. Picking up Anton C. Zijderveld's (1996) argument, Schmidt points out that comedy should thus be regarded as a 'social shelter', in which the playful subversion of the symbolic representation of reality can be accomplished safely and without fear of consequences for the communicators. A special communicative form of conversation opening implements this. Opening lines in jokes or title cards in comedy shows on television, for example, serve this function. The playful subversion of established social reality is facilitated on the content-level of the message. Here, the communicator constructs semantic incongruences, as s/he joins two (or more) propositions with an established societal meaning, which otherwise do not coincide. This could be, for example, an established representation of a certain group of immigrants placed in an 'unusual' setting, which is not part of the regular depiction in the majority. This incongruence needs to be resolved by the audience in order to be playful and without consequences. This is signified through laughter. In the case of social interactions such behaviour can easily be observed. In mediatised settings, special precautions have to be taken to grant success. A live audience might provide direct feedback of their understanding and processes of decoding through laughter in a comedy show; in sitcoms, so-called 'laugh tracks' or 'canned laughter' are overdubbed in order to prompt the audience in front of the TV towards the comical intent. Nevertheless, laughter is no unconditional result in this constellation as the audience might decide not to laugh in order to sanction a comedian whose humour is 'off the rails'.

In addition to the so far described societal level, the social-psychological level of comedy promotes two effects: it is an inclusive process for those who laugh together, but excludes those who are derided. These processes are a form of playful negotiations of power as well. For example, the underlying process of comical communication could be used to safely voice an unpopular opinion in an oppressive environment (Paletz 1990), but at the same time could be used to oppress a certain group of people by joking about them (Schmidt 2002). Nevertheless, this stigmatisation can lead to processes and practices of self-identification of the group who has been mocked. Thus, comical communication is a double-edged sword, 
which allows oppression and emancipation at the same time (Stillmann, Baumeister \& deWall 2007). Strikingly, if members of a certain oppressed or negatively connoted social group, such as migrants, get the opportunity to joke about themselves, negative connotations are weakened, as they gain the chance to reclaim communicative power. Thus, comical communication used by migrants can provide a helpful way of social integration, as it reduces perceived negative connotations and enables identification with the migrants and through this can integrate them into larger societal structures (Kotthoff, Jashari \& Klingenberg 2013; Müller 2009).

Summing up, mediatised comedy can be seen as a way to promote social inclusion of migrants through subversive forms of symbolic construction of reality. Nevertheless, the comical communication has to be conducted by migrants, about migrants and should be primarily aimed at a non-migrant audience, in order to reach its desired effect. Thus, the dominant representation of migrants given through journalism and other media can be subverted, which can result in new forms of representations of migratory life. These opportunities are rare, but can be found, for example, on StandUpMigranten, a special comedy show on German television, which gives a subversive voice to migrants. The title of the show is a play of the expression 'Stand-up', referring to the comedy genre, as well as to the political call for action of 'standing up' for one's rights.

\section{Between Traditional Kabarett and Modern Television Comedy: StandUpMigranten}

StandUpMigranten premiered on October $12^{\text {th }} 2013$ on the public broadcast channel eins|plus, a digital television channel which is part of Germany's longest running public television network $A R D$. It is recently running in its $3^{\text {rd }}$ season and enjoys reruns in the seasonal breaks. Hosted by German-Moroccan comedian Abdelkarim, each of the 23 episodes, running approximately 45 minutes each, features up to three stand-up comedians with a distinct migratory background. A shisha bar in Munich serves as a makeshift comedy club, rich with 'ethnic' and oriental (or orientalised, as Said (2003) would describe it) décor for comedians that perform in front of a live audience. The comedians' shtick is usually taken from their own life and experiences as migrants (or second or third generation immigrants) in Germany. Thematically, their routines deal with all aspects of migratory life, such as language difficulties, the German administrative system, or the process of migrating to Europe and Germany.

As a public television channel, its role is to inform, educate and entertain its audiences (Holtz-Bacha \& Norris 2001). This role is carried out by different channels of the network, whereas eins|plus, founded in 1997, features mainly educational, service-oriented programmes during the daytime and entertainment shows in its prime-time programming. Thus, comedy shows on these channels are usually highbrow in order to fulfil its public role, which is providing orientation with regard to political issues (von Rimscha, de Acevedo \& Puppis 2010), addressing an older, politically more sophisticated audience.

This role of political television comedy is rooted in the lively tradition of German Kabarett (comedy club), which is frequently set in small venues, usually nightclubs, with a small stage and a small live audience. Stand-up comedy is the most prominent element in Germany and satirically comments on on-going and recent political issues. It is known for its 'below-thebelt', black humour, which targets anything political using razor-sharp wit and blunt jokes 
alike. Anton C. Zijderveld's (1996) ideas on comedy as a social construct, which allows a safe disturbance of established societal rules, come to mind. Comedians take on a certain political issue, topic or personality and mock it by pointing out its flaws. Nevertheless, through the 'sanctity' of social rules, employed spatially through the specialised venue of the nightclub and legitimised by the laughter of the audience, this disturbance of established social order and evaluation is not to be punished, but to be dissolved harmlessly.

StandUpMigranten builds upon this traditional setting, but goes beyond established routines and practices of 'traditional German stand-up comedy'. As the latter was 'transformed' from Kabarett into television comedy (Reinhard 2006), it had to adapt to the rules and styles of television. This not only had an impact on the aesthetics of presentation, but on performances as well. Kabarett had to be made 'television-friendly', transformed from dimly lit venues to bright television studios. The audience was moved from their tables adjacent to the stage into rows of seats, making way for television cameras. Changes on the content-level had to be made as well. Since television shows are a commodity (Gitlin 1979; Kellner 1981), they are produced with a certain audience and a certain 'profit margin' in mind. In order to get a hold of the audience and keep them watching, the programme needs to be attractive to them, but must refrain from any content which is (too) offensive to avoid shrinking ratings and disapproval. Therefore, the comedians need to tone down their act in order to fit these requirements, without losing the edge of traditional satire and sharp political comment. StandUpMigranten manages to balance this transformation by respecting on the one hand the rules of traditional satire and on the other hand play with new forms television production offers.

They seem to make the best of both worlds by combining their features: taken from comedy is the setting of StandUpMigranten. It is filmed on location in a small shisha bar in Munich. This alone evokes an 'oriental' feeling for German audiences, as shisha-, or nargile-smoking is usually associated with urban, second- or third-generation migrants from Turkey or Arabic countries, and is often used by younger migrants in order to represent their Turkish (or other) identity (Reich \& Spitzner 2009). The setting's décor enhances this oriental 'look and feel', by placing the audience in the midst of a variety of carpets, ottomans and shishas. Furthermore, the show opens to the first bars of Arabic vocals of the song "Hadi Ya Bahardi" by Rajab Chamlakh, which evokes associations of the mu'adhdhin's calling to prayer. A narrator overdubs the song, welcoming the TV audience to the show and using its 'full name': StandUpMigranten: Comedy mit allem und scharf, which roughly translates to "StandUpMigrants: A comedy show with everything and hot sauce". This is a reference to a multi-ethnic German language variety called Kietzdeutsch, which is primarily spoken among adolescents with a migratory background in an urban context. It features a weakened form of German grammar rules in combination with forms of intonation commonly associated with Turkic and Semitic languages, as well as their specific vocabulary (Wiese 2011). The use of Kietzdeutsch is generally associated with migrants of lower socio-economic status and formal education, and is often imitated for humorous causes, as in this case. The mentioned phrase is a colloquial expression of doner kebab vendors, who offer a variety of sides, as well as hot sauce as a dressing. Customers are usually asked how their kebab should be garnished, with 'everything and hot sauce' being the default setting. The whole introduction is highly ambivalent: it seems to empower migrants, but builds on stereotypical depictions, such as the kebab vendor, without breaking these connotations. Thus, the German audience is presented once more with a feeling of constructed orientalism - through a phrase, which is familiar to them, but which also invokes differences in social positions through the use of Kitzdeutsch. The setting and introduction of the show, thus, is an homage to a traditional German 
comedy/Kabarett venue, but is 'orientalised' in order to set the tone of the show and become visually attractive for the televised broadcast.

A further reference to traditional comedy, which is adapted for television, is the live audience of the show. The roughly 200 audience members, consisting of non-migrants and migrants alike, are an integral part of the comedic aspects of the show as they provide direct feedback to the comedians, who often include them in their routines by breaking the fourth wall. The latter is established only implicitly, as the stage is nearly ground level and placed in the midst of the audience. This establishes a symbolic connection between the members of the audience and the performers, as they become 'one with the audience', which can be interpreted on a political dimension: migrants are part of German society, represented by the migrant and non-migrant audience members. They are, on performers' sides, 'centre stage' - and not backstage. The television audience is integrated into the live audience as well, as the show's host Abdelkarim hands out a handheld camera to one of the audience members, which allows him or her to tape the show from their point of view. This footage is integrated into the broadcast and thus strengthens the connection of the comedian to their various audiences the TV audience becomes part of the live audience. Thus, StandUpMigranten takes advantage of traditional Kabarett's immediacy and the spontaneity of audience reactions, and adapts these to the televised form.

\section{Migratory Life in Germany: The Cases of Jilet Ayse and Berhane Berhane}

StandUpMigranten mainly deals with cultural borders between migrants and non-migrants in Germany. The experience of migration with regard to political borders is scarce, but nevertheless to be found on the show. Among the comedians that appeared on StandUpMigranten, two comedians stand out who advance the stressed argument. First, the comedian Berhane Berhane, who appeared twice on the show, gives an account of the events at the German border when he arrived as a child immigrant. Second, the comedian Idil Baydar, better known by her stage name Jilet Ayse, describes the life of third-generation Turkish immigrants in Berlin and has appeared three times on StandUpMigranten. In order to gain insights into the comical treatment of migration, exemplary stand-up routines of these comedians are reviewed.

In his routine, the first-generation Ethiopian immigrant Berhane Berhane gives a detailed account of the events that happened to him during the process of immigration to Germany. Of underground fame, he made his way to the spotlight through the German comedy show Nightwash, a show that aims to provide a stage for young and new comedy talents. Berhane's shtick is a person who is subject to the 'absurdities' of the German administrative system. He uses a naïve character, which is confused by administrative processes and tries to confront the underlying rationale through common sense - which is destined to fail.

Berhane, named after his grandfather, is famous for his account of the events that occurred to him at the German border during immigration with his father Kassai. Coming from a society that follows the Habesha system of naming, only single, given names are used. In this system, further identification of a person is possible by referring to the name of that person's father. Not familiar with this naming system, the administrative agent is confused, since registration in Germany requires a first name and a surname, and simply decides to use the grandfather's first name as the surname or the family name, leading to Berhane's father named Kassai Berhane. Accordingly, Berhane was renamed as well following the same 
'logic' of simply joining his given name with his father's new surname, resulting in: Berhane Berhane. This confusing name caused problems throughout his life. Berhane gives insights of how having the same first and last name confuses again other agents of the German administrative system. In one of his appearances on StandUpMigranten, he tells the story of him being randomly selected for inspection at a German airport. Showing his valid ID card only led the border agent accuse him of ID forgery.

Berhane's narrations of institutional processes upon immigration rely heavily on making authoritarian acts laughable. He evokes images of historic processes of name changing upon immigration, most prominently those that occurred on Ellis Island in New York harbour at the turn of the $20^{\text {th }}$ century to Americanise 'foreign' names for easier immigration processing. Such acts can be interpreted as a symbolic act of violence, as a person's name represents his identity, which is radically changed in order to fit into a system that is only prepared for a certain system of naming and registration. The absurdities of these actions become obvious as the administrative system, represented by security forces, is not able to handle the effects of its own decision and blames the victim. By mocking these events, Berhane subverts the dominant idea of integration, which is often represented as a one-sided effort of 'fitting the foreigner in' - even at the price of his or her identity.

The forty-year old, second-generation Turkish immigrant Idil Baydar chooses a different approach for subverting dominant discourses on migration. Formerly of YouTube fame, Baydar became a known stand-up comedian. Her main character is the eighteen-year old, third-generation immigrant Jilet Ayse, an obnoxious, loudmouth Turkish working-class teenager who resides in the suburbs of Berlin. Dressing her character in cheap sweatpants and training jackets and letting her speak heavy Kietzdeutsch, she resembles a stereotypical Turkish teenager, who has nothing better to do than hanging out and causing (as well as looking for) trouble. Apart from this account of teenage life, Baydar uses her character to give a detailed account on the role of women in Turkish (and Islamic culture more generally) societies. In her routine, Baydar embarks from dominant imagery as she presents herself as the stereotypical teenage troublemaker, only to use this character to subvert the imposed image. In one of her performances on StandUpMigranten, she takes on stereotypical depictions of Turkish women, who carry heavy bags of groceries while their unladen husbands walk in front of them, appearing unimpressed. Using lyrics from rapper Tupac Shakur, she builds up incongruence, which she dissolves comically. "Your friends may have your back, but the bullet hits you from the front", she adapts from the gangsta-rapper, and thereby explains this seemingly oppressive behaviour: As the man walks in front of the woman with his hands free, he is ready to take on any threat against her, that might occur. Thus, she gives a positive connotation to the men's behaviour. Another instance of her subversive strategy is her take on the alleged seclusion of Turkish women who are confined to their homes, protected by male members of their families. Again, Baydar lets Jilet Ayse explain the circumstances of this behaviour: As women are regarded as 'treasures', they need to be protected. Thus, she again, gives a positive background of this social situation.

Idil Baydar's strategy of using comedy is therefore empowering in two ways. First, through subversive communication she levels the negative representation of gender-inequality and reinterprets them positively. Second, she uses stereotypical depictions of Turkish teenagers in order to get the non-migrants audience's attention. She breaks down the cultural border that separates these two groups by showing that there is no need to loathe or fear the 'strange' behaviour of Turkish teenagers, as they act in accordance with their own cultural background and identity. 


\section{Conclusion: How Does Comedy Add to Political Discourse?}

How can comedy subvert dominant discourses on the issue of migration? In light of the above review, the answer to this question requires a more differentiated discussion. Although comedy refutes the conservative idea of 'Fortress Europe' by national-level policies on immigration, negative images of migrants are still perpetuated by journalistic media and politics. Nonetheless, as the case of Germany shows, counter-rhetoric is possible, and even bears the option of political emancipation through comedy, especially if used by the migrant comedians themselves. There are methodological and theoretical limitations with regard to this argument. Methodologically, this paper has given an exemplary review of two comedians and their approach to playfully subvert the dominant discourse on migration in Germany through personalized accounts. In order to evaluate the success of comedy as a discursive strategy, a broader analysis on the content level is required and is currently conducted. As described above, comedy has the power to safely give personal accounts of migratory life and their underlying processes. Thus, through explanation of cultural circumstances and differences by comedians with the corresponding background, cultural borders are lowered and a mutual understanding becomes possible. As the audience gets the joke, it starts processing it cognitively, facilitating learning and, in some cases, the re-thinking of stereotypical assumptions (Schneider, Bartsch \& Gleich 2015). Theoretically, limitations have to be taken into account stemming from the mechanisms of comedy itself: after the laughter is gone the subversion has ended. StandUpMigranten is part of the public television system, which commodifies the comical accounts of migration, thus subduing them to economic processes. Accordingly, the subversive strategy becomes part of an established mode of cultural production, which is in line with Horkheimer's and Adorno's (2003) findings on the cultural industry, which promises emancipation but denies it at the same time. This becomes visible in the show's setting: the orientalised stage is chosen to familiarize the audience with the topic of migration, but fails to give a 'true' depiction of migratory life. Furthermore, the show's introduction, which relies heavily on Kiezdeutsch, emphasizes the difference between migrants and non-migrants, instead of abolishing it.

In conclusion, this article argues that the show StandUpMigranten serves as a valuable addition to the political discourse on migration in Germany as it gives a voice to groups of people who are otherwise silenced. Personal reports of traveling to Europe and Germany and experiences of crossing political and cultural borders are a valuable addition to the conservative reporting of these processes, which is often distant and impersonal. The strength of Kabarett lies in the connection of the comedians with their audience through personal accounts. Its rhetorical strategy deviates from dominant discourses and playfully subverts them by making them relatable - and laughable. Thus, comedy has the power to open the gates of 'Fortress Europe' one joke at a time.

\section{References}

Bade, K. J. (2015) 'Zur Karriere abschätziger Begriffe in der deutschen Asylpolitik' [On the career of defamatory expressions in German asylum politics], Aus Politik und Zeitgeschichte [Politics and Contemporary History], 65, 25, 3-8

Geiges, L., Marg, S., \& Walter, F. (2015) Pegida. Die schmutzige Seite der Zivilgesellschaft? [Pegida. Civil Society's Dirty Side?], Bonn: Bundeszentrale für politische Bildung [Federal Agency for Civic Education] 
Gerson, O. (2015) 'Frontex und die europäischen Außengrenzen' [Frontex and Europe's borders], Aus Politik und Zeitgeschichte [Politics and Contemporary History], 65, 25, $43-$ 49

Gitlin, T. (1979) 'Prime time ideology: The hegemonic process in television entertainment', Social Problems, 26, 3, 251-266

Hall, S. (1979) 'Encoding/Decoding', in S. Hall, D. Hobson, A. Lowe and P. Willis (eds.), Culture, Media, Language. Working Papers in Cultural Studies (1972-1979) London: Routledge, pp. 128-138; 294

Herbers, M. R. (2014). 'Do the media fail to represent reality? It depends', Constructivist Foundations, 10, 1, 216-217

Holtz-Bacha, C., \& Norris, P. (2001) “"To entertain, inform, and educate". Still the role of public television', Political Communication, 18, 2, 123-140

Horkheimer, M., \& Adorno, T. W. (2003) 'Dialektik der Aufklärung' [Dialectic of enlightenment], in M. Horkheimer (ed.), Gesammelte Schriften. Band 5: >Dialektik der Aufklärung und Schriften 1940-1950 [Collected Writings. Volume 5: >Dialectic of enlightenment and Writings 1940-1950], Frankfurt am Main: Fischer, pp. 13-290

Kellner, D. (1981) 'Network television and American society: Introduction to a critical theory of television', Theory and Society, 10, 1, 31-62

Kotthoff, H., Jashari, S., \& Klingenberg, D. (2013) Komik (in) der Migrationsgesellschaft [Comedy of/in the Migratory Society], Konstanz and München: UVK

Lichtenstein, D. (2012) 'Auf der Suche nach Europa. Identitätskonstruktionen und das integrative Potential von Identitätskrisen' [In search for for Europe. Construction of identity and the integrative potential of identity crises], Aus Politik und Zeitgeschichte [Politics and Contemporary History], 62(4), 3-7

Mayring, P. (2015) Qualitative Inhaltsanalyse. Grundlagen und Techniken [Qualitative Content Analysis. Fundamentals and Techniques], Weinheim and Basel: Beltz

Müller, F. (2009) 'Entertaining anti-racism. Multicultural television drama, identification and perception of ethnic threat' Communications, 34, 3, 239-256

Paletz, D. L. (1990) 'Political humor and authority. From support to subversion', International Political Science Review, 11(4), 483-493

Reich, S., \& Spitzner, F. (2009) 'Veränderung stereotyper Wahrnehmung durch Ethno-Soaps. Eine Untersuchung am Beispiel der Serie Türkisch für Anfänger' [The transformation of stereotypical perception through ethno-soaps, exemplified by the series Turkish for Beginners], in T. Petersen and C. Schwender (eds.), Visuelle Stereotype [Visual stereotypes]. Köln: von Halem, pp. 44-57

Reinhard, E. (2006) Warum heißt Kabarett heute Comedy? Metamorphosen in der deutschen Fernsehunterhaltung [Why is Cabaret Called Comedy Nowadays? Metamorphoses in German Entertainment Television], Münster: LIT

von Rimscha, B., de Acevedo, M., \& Puppis, M. (2010) “"Relevant, was Werte und Normen betrifft". Public Value von TV-Unterhaltung in Klein- und Großstaaten' ["Relevant with regard to values and norms". Public value of TV-entertainment in smaller and larger nations], Medien Journal [Media Journal], 2, 3-14

Said, E. W. (2003) Orientalism, London: Penguin 
Schmidt, A. (2002) 'Aggressiver Humor in den Medien - am Beispiel der Fernseh-ComedyShow "tv total." [Aggressive humour in the media - the case of the television comedyshow "tv total"], Medien \& Kommunikationswissenschaft [Media and Communication Science], 50, 2, 195-226

Schmidt, S. J. (2003) 'Unterhaltung gibt es nicht. Unterhalten Sie sich gut! Einige philosophische Anmerkungen zum Thema' [There is no entertainment. Entertain yourself! Some philosophical remarks on that topic], in W. Früh and H.-J. Stiehler (eds.), Theorie der Unterhaltung. Ein interdisziplinärer Diskurs [Theory of Entertainment. An Interdisciplinary Discourse], Köln: von Halem, pp. 324-336

Schmitz-Berning, C. (2000) Vokabular des Nationalsozialismus [Vocabulary of National Socialism], Berlin: de Gruyter

Schneider, F. M., Bartsch, A., \& Gleich, U. (2015) 'Spaß, Spannung...Denkanstöße? Hedonische und eudaimonische Gratifikationen, Bewertungen und Folgen der Rezeption von Stefan Raabs Sendung "Absolute Mehrheit." [Fun, suspense...food for thought? Hedonic and eudemonic gratifications, evaluation, and effects of the reception of Stefan Raab's show “Absolute Majority”], SC $\mid$ M. Studies in Communication|Media, 4, 1, 53-68

Schulz, W. (1989) 'Massenmedien und Realität. Die "ptolemäische“ und die "kopernikanische" Auffassung' [Mass media and reality. The "Ptolemaic" and "Kopernikanic" view], in M. Kaase and W. Schulz (eds.), Massenkommunikation. Theorien, Methoden, Befunde [Mass Communication. Theories, Methods, Findings], Opladen: Westdeutscher Verlag, pp. 135-149

Stillmann, T. F., Baumeister, R. F., \& DeWall, C. N. (2007) 'What's so funny about not having money? The effects of power on laughter', Personality and Social Psychology Bulletin, 33, 11, 1547-1558

Vick, K., \& Schuster, S. (2015) 'Chancellor of the free world', [online], 21 December. Available at http://time.com/time-person-of-the-year-2015-angela-merkel/. Accessed 22 April 2016.

Wiese, H. (2011) 'The role of information structure in linguistic variation. Evidence from a German multiethnolect', in F. Gregersen, J. K. Parrot, and P. Quist (eds.), Language Variations. European Perspectives III. Selected Papers From the 5th International Conference on Language Variation in Europe (ICLaVE 5), Copenhagen, Juni 2009, Amsterdam, Philadelphia: John Benjamins Publishing Company, pp. 83-96

Zandonella, B. (2009) Pocket Europa. EU-Begriffe und Länderdaten [Pocket Europe. Terms of the EU, and National Data], Bonn: Bundeszentrale für politische Bildung [Federal Agency for Civic Education]

Zijderveld, A. C. (1996) 'A sociological theory of humor and laughter', in L. Fietz, J. O. Fichte, \& H.-W. Ludwig (eds.), Semiotik, Rhetorik und Soziologie des Lachens. Vergleichende Studien zum Funktionswandel des Lachens vom Mittelalter zur Gegenwart [Semiotics, Rhetoric, and Sociology of Laughter. Comparative Studies on the Functional Change of Laughter From the Middle Ages to Present Time], Tübingen: Niemeyer, pp. 3745 
Dr. Martin R. Herbers works as at a PostDoc at Zeppelin Universität, Friedrichshafen, Germany. His research interests are in the field of critical entertainment research and the contribution of political comedy to the public sphere.

Email: martin.herbers@zu.de 